\title{
肝切除症例に括ける分枝鎖アミノ酸投与の臨床的意義
}

久留米大学医学部第 2 外科（主任：古賀道弘教授）

浜崎恵

\section{CLINICAL SIGNIFICANCE OF BRANCHED CHAIN AMINO ACIDS TRANSFUSION IN HEPATECTOMIZED PATIENTS}

\author{
Kei HAMASAKI \\ Second Department of Surgery, Kurume University School of Medicine \\ (Director : Prof. Michihiro Koga)
}

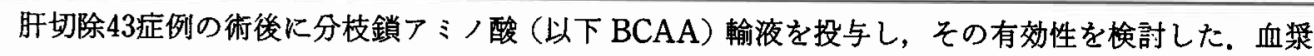
アミノ酸は術後21日目まで測定し, HPT, $\mathrm{NH}_{3}, \mathrm{GOT}, \mathrm{Alb}$ は術後14日目までの值を対照 37 症例と比 較した。術前, 肝硬変例に血浆アミノ酸のインバランスが認められたが, BCAA 輸液投与により補正 された。また BCAA 輸液は術後のアルブミン合成を初めとする蛋白合成に促進的に働く一方, 明らか な $\mathrm{NH}_{3}$ 低下作用を示し, 術後の $\mathrm{NH}_{3}$ 上昇防止に有用であった。ささらに術後早期のェネルギー源として の有用性も示唆され, 肝切除後の栄養輸液の一つとして, BCAA 輸夜は適しているすのと思われた。

索引用犃：肝切除術後の栄養輸液, 栄養輸液と分枝鎖 $ミ$ ノ酸

はじめに

肝は膨大な予備能と旺盛な再生能を持つ葴器であ ク, 正常な訮であれば, 肝大量切除にても量的, 機能 的に一定の時間で順調に回復することが多い.しかし， わが国において最す肝切除の対象となる原発性肝癌は 肝硬変合併例が多く, 肝切除後, 常に肝不全を招来す る危険性をはらんでおり, 術後の管理, 特に栄養代謝 管理は非常に重要と言える. 肝切除後の肝不全の病態 はいまだ明らかとは言えないが, 術後栄養としての糖 の種類，その投与量, Insulin, glucagonなどいわゆる hepatotrophic factor の投与 ${ }^{1)}$, またアミノ酸輸液の配 合比などを工夫, 検討することにより, 残存肝の再生 を円滑に進め, さらに術後の異化期を迅速に離脱させ たならば，肝不全を回避でさるのではないかと諸家に

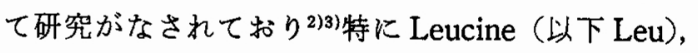
Isoleucine（以下 Ileu）, Valine（以下 Val）の分枝鎖 アミノ酸 (以下 BCAA) の効果が注目されている.重 症肝疾患や肝切除後に血浆遊離アミノ酸のインバラン スが認められることは以前より知られていたが4), 1976年, Fischer ら5゙が肝障害患者に, このインバラン

$<1985$ 年 9 月 11 日受理>別刷請求先：浜崎 恵 干801 北九州市門司区浜町 3-23 門司労多病院外 科
スを補正する目的で, Branched chain amino acids(以 下 BCAA) 輸液（Fischer 夜）を考案し，著しい臨床 効果を報じて以来, わが国に招いても，この Fischer 液 に準じた BCAA 製剂（表 1）が作成され（Tokyo University Hospital Fluid (以下 THF) ほか) (7)7), 特 に内科疾患 (劇症肝炎, 肝硬变注か) に対する効果が 検討されてきだ). 今回，われわれは，この BCAA 輸 液が, 肝切除後の栄養輸夜として適しているかどうか を, 肝切除後の血浆アミノ酸異常の補正, さらに肝再 生促進, ひいては肝不全の予防という点から, 血浆》 ミノ酸の測定を中心に種々の血清学的データより検討 した。

\section{対象}

昭和58年 6 月までに肝切除43症例に対して術後 THF を投与した，投与症例の内訳は（表 2 ）原発性肝 癌 39 例, 胆管癌 1 例, 肝内結石症 2 例, 肝血管腫 1 例 であり，その術式は 2 区域切除15例，1区域切除 5 例, 亜区域切除 6 例, 部分切除17例, 硬变併存は28例であっ た. 性別は男33例，女10例と男性が多く，年齢は平均 57.2 歳 (35 76歳) であった。術前肝機能予備力の平 均値は術式別に 2 区域切除では血清 albumin（以下 Alb) 3.8, 血清 cholinesterase (以下 chE) 0.66, ICG 15分值 (以下 15 'ICG) 16.2 , ICG 消失率 (以下 KICG) 
表 1 投与した分枝鎖アミノ酸製剂の組成

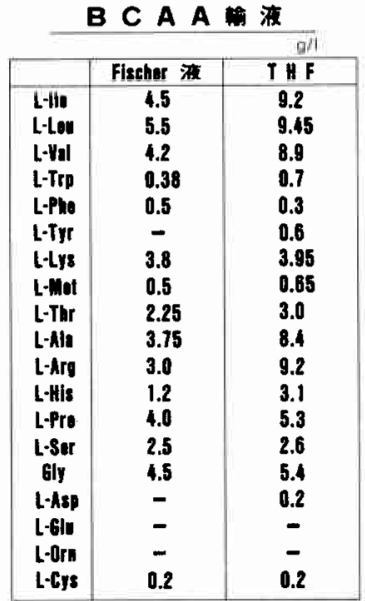

表 2 THF 使用䀒切除症例

\begin{tabular}{|c|c|c|c|c|c|c|c|c|}
\hline No & 氏名 & 性 & 年 命 & 急 & 名 & 种展变 & 手政票式 & 合件症 \\
\hline 1 & H. E & f & 55 & 訮到胞 & & + & 2 区场切绦 & 所 不 全 \\
\hline 2 & $M$ & 자 & 57 & 肝 湅 胞 & 浻 & + & 1区域切腺 & $\longrightarrow$ \\
\hline 3 & $Y$ & $\delta$ & 47 & 肝湅跑 & 翮 & + & 部分切䧆 & 的 不 \\
\hline 4 & 1 & $\hat{s}$ & 52 & 肝细胞 & 檻 & + & 部分切䁖 & 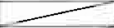 \\
\hline 5 & $\mathbf{T}$ & 우 & 58 & 研内拮石 & & - & 2区场切 & r \\
\hline 6 & M & $\delta$ & 75 & 胆管洞胞 & & + & 1 区场切标 & ヒビリルビン用合 \\
\hline 7 & 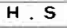 & $\hat{\delta}$ & 52 & 所袖咆 & 畺 & - & 2 区场切啋 & 雨化需出 血 \\
\hline 8 & 1 & 3 & 60 & 肝耦胞 & 表 & + & 部分切绦 & 心 不 全 \\
\hline 9 & $\mathrm{H}$ & $\Sigma$ & 47 & 肝湖狍 & 雷 & + & 嘼分切脱 & ธピリルビン胆 \\
\hline 10 & $M$ & 6 & 62 & 肝檣胞 & 盍 & + & 部分切除 & 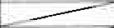 \\
\hline 11 & S. Y & $\delta$ & 70 & 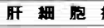 & s & + & 部分切榢 & $\ldots$ \\
\hline 12 & $\mathbf{M}, \mathbf{m}$ & 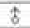 & 55 & 肝榊 & 乘 & + & 㰻分切除 & 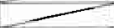 \\
\hline 13 & . $\mathrm{K}$ & $\hat{\delta}$ & 49 & 畈理 & 量 & + & 1 区场级绦 & 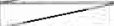 \\
\hline 14 & K, 1 & $\delta$ & 66 & 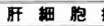 & 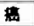 & - & 部分切除 & 外胆 汁 \\
\hline 15 & K. N & 우 & 35 & 肝内粭石 & 在 & - & 2区场切绦 & $\longrightarrow$ \\
\hline 16 & iv $\mathrm{H}$ & 8 & 56 & 肝理 & 惠 & - & 2 区场切 & - \\
\hline 17 & I.T & q & 39 & 胙血零 & 需 & - & $2 区$ 切绦 & . \\
\hline 18 & M & 6 & 55 & 肝 赥胞 & 惠 & + & 新分切除 & 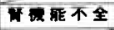 \\
\hline 19 & $M$. & 우 & 59 & 胆 管 & 雷 & - & $2 区$ 场切㹣 & $\longrightarrow$ \\
\hline 20 & $t$ & 6 & 55 & 䏦 籶 胞 & 舴 & + & 要区域切啋 & \\
\hline 21 & 5 & $q$ & 59 & 䀒 細 帮 & 埇 & + & 亜区域切淂 & \\
\hline 22 & & 9 & 53 & 肝 蜔 胞 & 澧 & + & 部分切除 & 忓性譄厔 \\
\hline 23 & $\mathrm{H}$ & T & 56 & 旰 䀅 胞 & 骠 & + & 2 区场切除 & $\longrightarrow$ \\
\hline 24 & A. M & 8 & 37 & 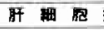 & 需 & + & 2 区域切除 & 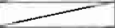 \\
\hline 25 & $N$ & $\hat{\sigma}$ & 57 & 肝 细 胞 & 舟 & + & 䣓分 切 除 & \\
\hline 26 & $\mathrm{~K}$ & $\hat{b}$ & 65 & 肝粈 晆 & 船 & + & 2 区场切除 & \\
\hline 27 & $T \cdot N$ & to & 60 & 肝䄄胞 & 害 & - & 血区场切除 & 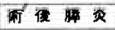 \\
\hline 28 & M. S & 오 & 67 & 肝 湅 圆 & 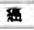 & - & 2 区场切除 & 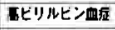 \\
\hline 29 & K. H & $\delta$ & 52 & 肝 紐 胞 & 感 & + & 垔区场切绦 & \\
\hline 30 & M. I & 8 & 76 & 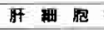 & 露 & - & 垔区域切除 & 河後睟炎 \\
\hline 31 & $T, H$ & t & 64 & 䏦 细 胞 & 盘 & - & $1 区$ 切绦 & 肝 不 全 \\
\hline 32 & $H . Y$ & 8 & 52 & 肝 湅 胞 & 清 & - & $2 区$ 场璠 & 累的能不全 \\
\hline 33 & $\mathbf{M}, \mathbf{K}$ & 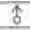 & 68 & 肝 蜔 胞 & 㜔 & - & 2区场切绦 & - \\
\hline 34 & $F \cdot T$ & 우 & 57 & 肝 湅 胞 & 程 & + & 部分切际 & \\
\hline 35 & $\mathbf{H}, \mathrm{K}$ & 8 & 60 & 肝 钿 胞 & 舟 & + & 部分切除 & 1 \\
\hline 36 & S.N & q & 52 & 肝 知 胞 & 露 & + & 部分切除 & 骨ビリルビン血症 \\
\hline 37 & $k, 1$ & $\frac{1}{6}$ & 58 & 腄 细 胞 & 煎 & - & 2 区圾切跙 & 外些计 \\
\hline 38 & $T$ & 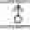 & 56 & 肝 細 胞 & 婹 & - & 2 区场切除 & 術後肝炎 \\
\hline 39 & MI & 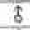 & 62 & 肝 細 胞 & 露 & + & 1区场切绦 & \\
\hline 40 & $\mathrm{~K}$ & ร & 54 & 肝 細 胞 & 程 & + & 垔区场切除 & 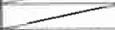 \\
\hline 41 & $E$ & 9 & 62 & 肝 细 胞 & 峦 & + & 部分切除 & 雨很出 血 \\
\hline 42 & $M$ & $\hat{\delta}$ & 71 & 肝湅胞 & 盘 & + & 新分切除 & 水 \\
\hline 43 & K. N & है & 57 & 䀒 細 胞 & 盘 & + & 部分切 除 & \\
\hline
\end{tabular}

0.233 , ICG 最大除去率(以下 R max) 1.4, hepaplastin test (以下 HPT) 81.9, total bilirubin (以下 T.B) 0.8であり，1区域切除では Alb 3.6, chE 0.62，15'I
表 3 THF 投与，末投与肝切除症例とその術式

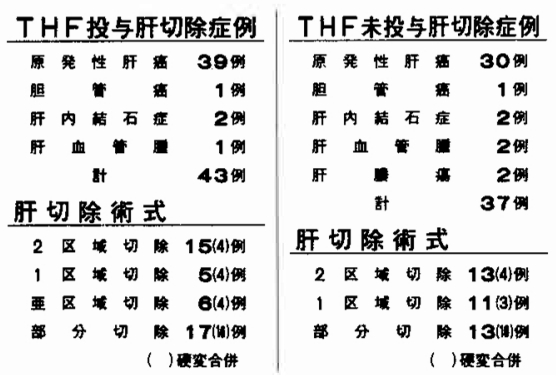

CG 12.9, KICG 0.139, $\mathrm{R} \max 1.2, \mathrm{HPT} 66.3$, T. B 0.8, 亜区域切除では Alb 3.4, chE 0.48, 15'ICG 22.9, KICG 0.126, $\mathrm{R} \max 1.1$, HPT 83.2, T.B 1.0, 部分切除では Alb 3.5, chE 0.49, 15'ICG 26.4, KICG 0.124, R max 1.3, HPT 64.5, T.B 1.0であった. 術後合併症は肝不全, 高ビリルビン血症, 術後䐙炎, 堅機能不全などが認められ，訮不全 3 症例が今回の術 後入院中に死亡した. THF 投与症例43例の術後14日 目までの HPT, 血清 ammonia（以下 $\mathrm{NH}_{3}$ ），血清 transaminase(以下 GOT), 血清 Alb, 血清 total bilirubin(以下 T.B)を THF 未投与37症例と比較検討した が，末投与例の内訳は（表 3）原発性肝癌30例, 胆管 癌 1 例, 肝内結石症 2 例, 肝血管腫 2 例, 肝膿瘍 2 例 であった。

\section{万 法}

今回の43症例の術後輸液は（表 4) 糖液として 20〜 50\%Glucose 液を投与し，insulinをGlucose 5 $\sim 8 \mathrm{~g}$ に 1 単位, glucagon は2 4mg/day 使用した. 7 日目までの投与総カロリーは, 平均 $1233 \pm 490 \mathrm{cal} /$

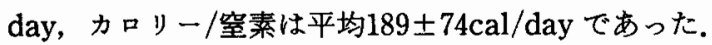
凍結血浆は術後 7 日目までに800 1,200ml/day 使用 し, THF は $500 \mathrm{ml} /$ day を術直後より平均 14 日間, 午前

\section{表 4 対象肝切除症例の術後基本輸液}

\begin{tabular}{|c|c|}
\hline & 腹流内容 \\
\hline フドウ縹 & $\begin{array}{c}20 \sim 50 \% \text { 嚆滳にて } \\
0.1 \sim 0.4 \mathrm{~g} / \mathrm{kg} / \mathrm{hr}\end{array}$ \\
\hline 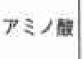 & $\begin{array}{l}\text { THF } 500 \mathrm{~m} \ell / \text { 日 } \\
\text { 術声後より平均14日間 }\end{array}$ \\
\hline カロリー & $\begin{aligned} \text { 衍後7日目まで } \\
\mathrm{Ca}: 1233 \pm 490 \mathrm{cal} \\
\mathrm{Cal} / \mathrm{N}: 189 \pm 74 \mathrm{cal}\end{aligned}$ \\
\hline 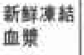 & $\begin{array}{l}\text { 術後7日目まで } \\
\text { 平均 } 800 \sim 1200 \mathrm{ml} / \text { 日 }\end{array}$ \\
\hline 芜の他 & 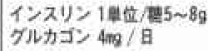 \\
\hline
\end{tabular}


9：00から午後 $12 ： 00$ までに投与した。血浆アミノ酸 の測定は術後21日目まで, 日立自動アミノ酸分析器に て行った. HPT, $\mathrm{NH}_{3}, \mathrm{GOT}, \mathrm{Alb}, \mathrm{T} ・ \mathrm{~B}$ は THF 投与 例, 未投与例ともに術後14日目まで隔日に測定し両者 を比較検討した，採血はすべて早朝空腹時に行った。

\section{結 果}

1. 術前血浆厂ミノ酸値 (図 1)

術前の血浆アミ，酸分析にて, Methionine (以下 Met), BCAA, 芳香族 $\urcorner ミ$ / 酸 (Phenylalanine+ Tyrosine, 以下 AAA), BCAA/AAA (以下 molar rate : MR) の値を硬変併存の有無で比較すると, Met では硬変例が高く, BCAA では硬変例が低い傾向に あった．さらに AAA は硬変例で有意の差をもって高 くなっており，MRる硬变例で有意に低値を示した。

2. Met, BCAA, AAA, MR の術後推移

図 1 術前の血浆フミ/酸値

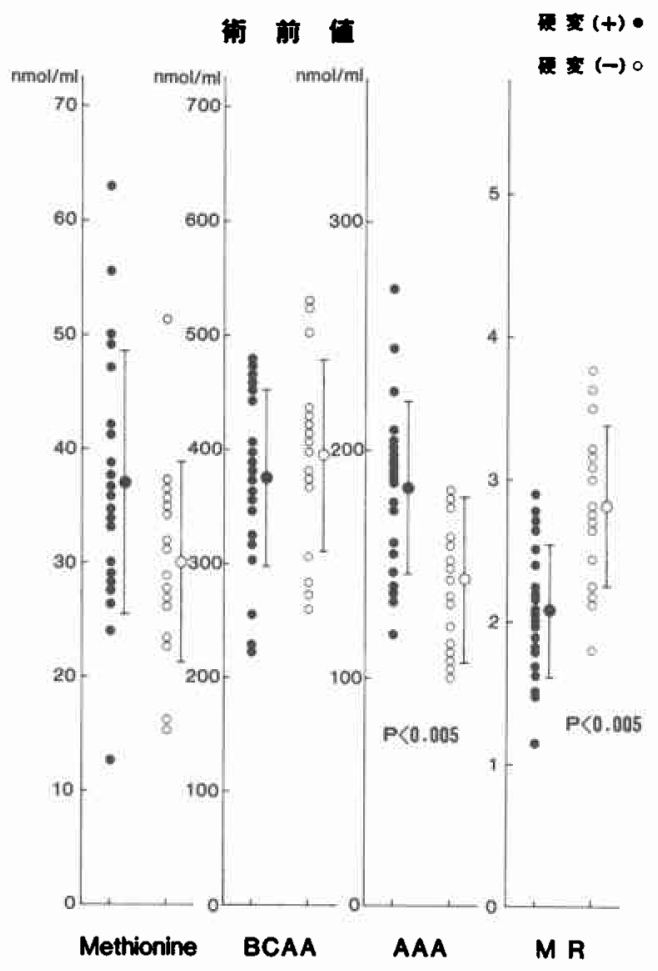

BCAA : Leucine+Isoleucine+Valine である branched chain amino acids（分枝鎖アミ，酸）の 略

AAA : phenylalanine+Throsine である aromatic amino acids (芳香族アミ/酸) の略

MR : Leucine + Isoleucine + Valine/ Phenylalanine+Throsineである molar rate の略
以上のような術前値を示した Met，BCAA，AAA， MRが，肝切除後，THF を投与することにより，ぞの ような值で推移するのか倹討した．Met は（図 2 上） THF に少量含まれているが, 術前34.05 $\pm 11.54 \mathrm{nmol} /$ $\mathrm{ml}$ あったものが術後 1 日目に $18.02 \pm 10.13 \mathrm{nmol} / \mathrm{ml}$ と低下した後，3日目，5日目と日を経るにつれて増 加，7日目に術前値よりわずかに高い值をで上昇し， その後は大きな変動は示していない，硬変の有無によ る違いは7 日目までは，ほほ術前值の差のままで硬変 例が高値で推移した，THFに高濃度含まれる BCAA は (図 2 下)，術後 1 日目に，術前の $382.80 \pm 80.63$ $\mathrm{nmol} / \mathrm{ml}$ から $296.26 \pm 99.01$ と低下した。しかし, 術後 3 日目には, すぐに $418.99 \pm 244.75 \mathrm{nmol} / \mathrm{ml}$ を示し, 術前值以上に回復, その後も著しい低下は示さず推移 した. 硬変例は 3 日目に481.75 285.79 , 非硬变例は, それより遅れて 5 日目に486.51士285.87を示し，それ ぞれのピークを認めた。AAA（図 3 上) も Met と同様 にTHFに少量含まれているが，術後 1 日目149.33土

図 2 Met, BCAA の術後推移

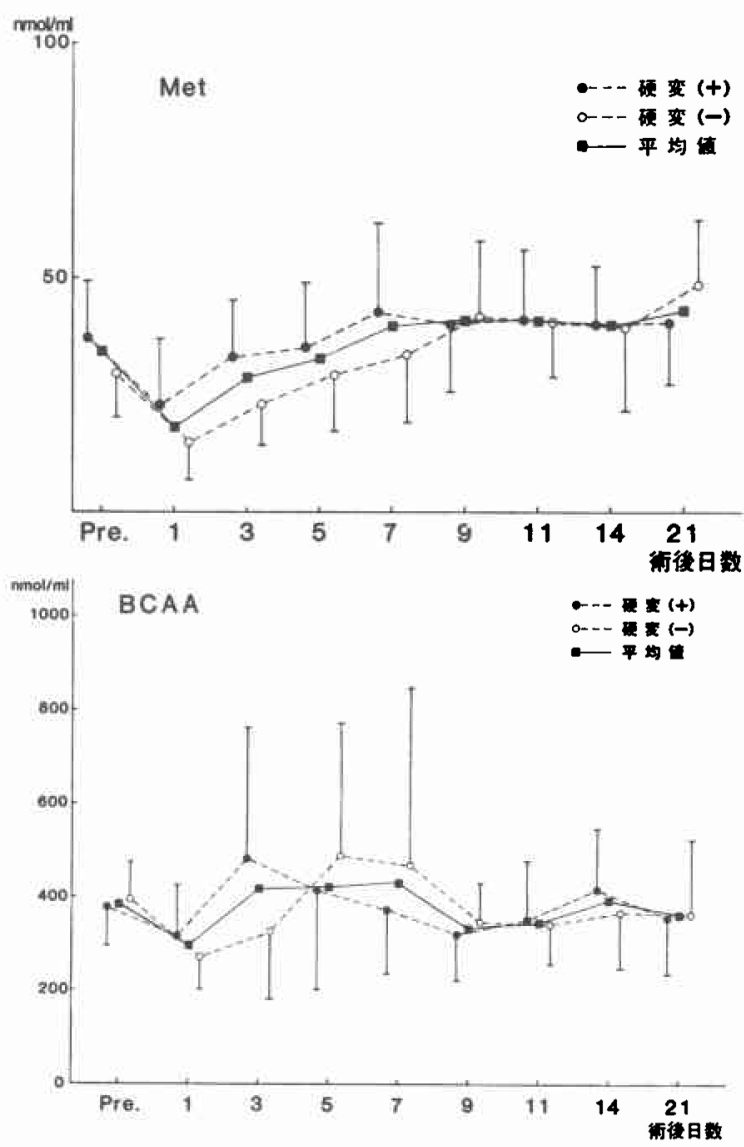


62.87 と低下した後, 徐々に増加傾向が認められた。し かし，その增加も極端な上昇はなく，特に硬变例でさ 著しい高値を示すことなく推移した，MRは（図 3 下）術後 7 日目玉では術前とほぼ同様の值で推移した 後，9 日目，11日目にそれぞれ1.64士0.573，1.67士 0.475 と低値を示した。しかし，全経過を通して 1.0 以 下の著しい低值を示すことはなかった，

3. $\mathrm{THF}$ 投与群と末投与両者間の術後 HPT, Alb, $\mathrm{NH}_{3}, \mathrm{~T} \cdot \mathrm{B}, \mathrm{GOT}$ 值の比較

$\mathrm{HPT}, \mathrm{Alb}, \mathrm{NH}_{3}, \mathrm{~T} \cdot \mathrm{B}, \mathrm{GOT}$ を THF 投与群，未投 与群とも術後14日目まで測定し, 両者の值をそれぞれ 比較することにより THF がこれらの検査データにど のように影響するのかを検討した，HPTでは(図 4)， THF 投与群の術前値 $74.87 \pm 16.44 \%$ は末投与群の術 前値 $84.89 \pm 13.21 \%$ より有意低值を示したが, 術 後には 1 日目に若干低下するるのの 3 日目にはほぼ術

図 3 AAA，MR の術後推移
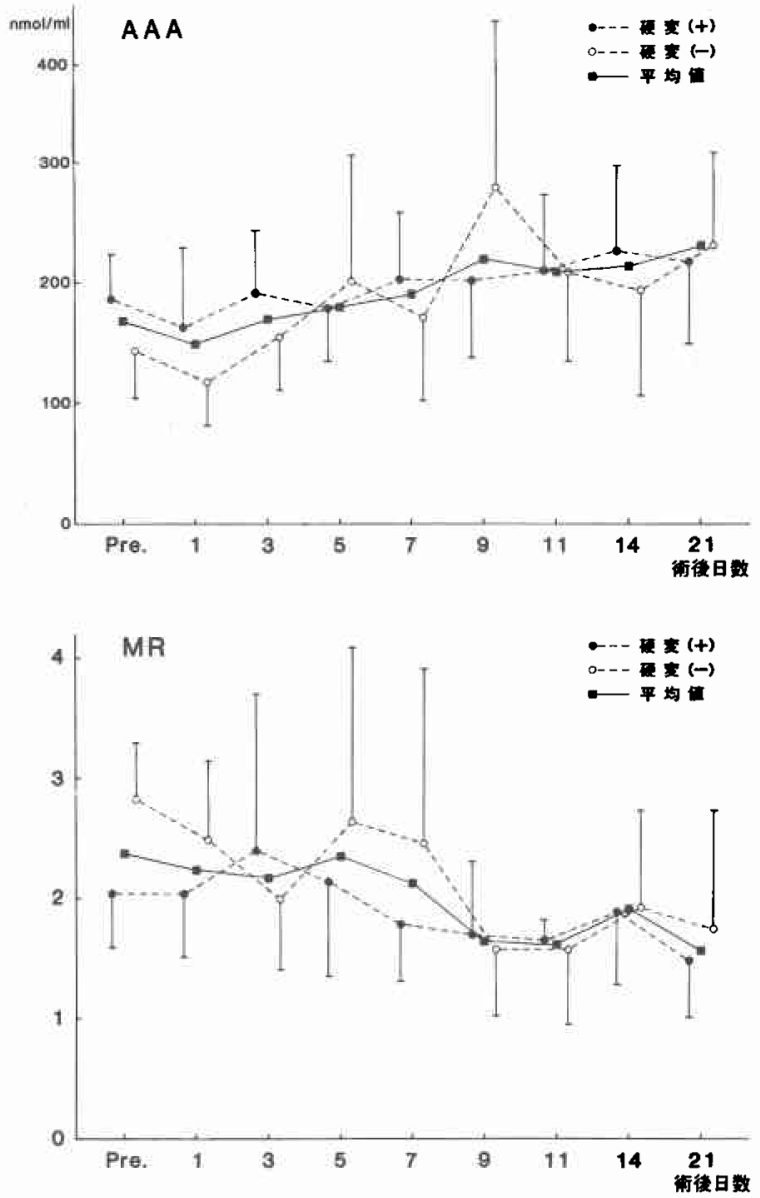

図 4 THF 投与群と末投与群間の HPT 值の比較

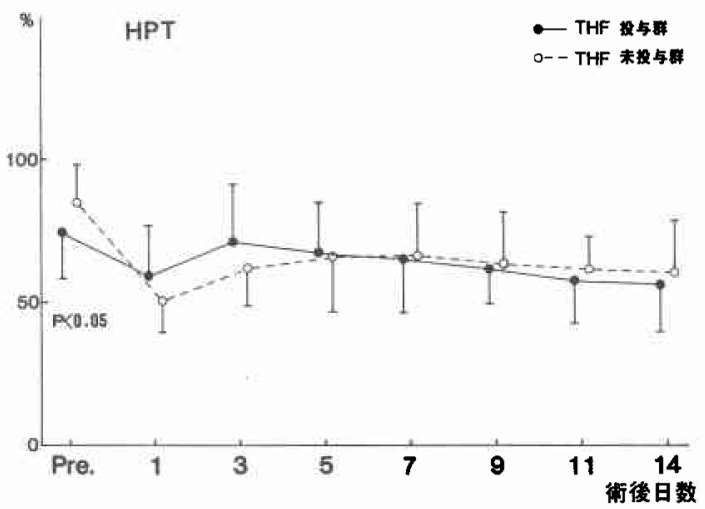

前値近くにまで回復し，特に $1,3 ， 5$ 日目は術前値と は逆に未投与群よりも高値を示した。これに対し $\mathrm{THF}$ 未投与群の場合, 術後 1 日目に著しく低下した 後, 徐々に上昇はしているが，結局は術前値よりかな り低値で推移した．Alb も（図 5) HPT と同じく術前

図 5 THF 投与群と末投与群間の alb 值の比較

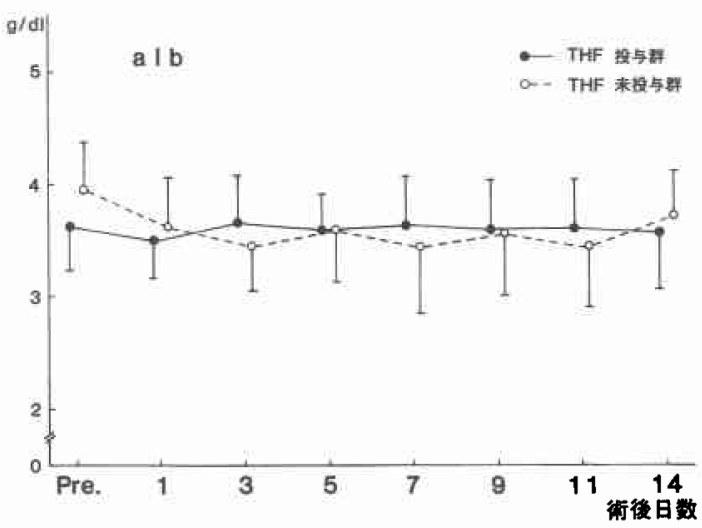

因 $6 \mathrm{THF}$ 投与群と未投与群間の $\mathrm{NH}_{3}$ 値の比較

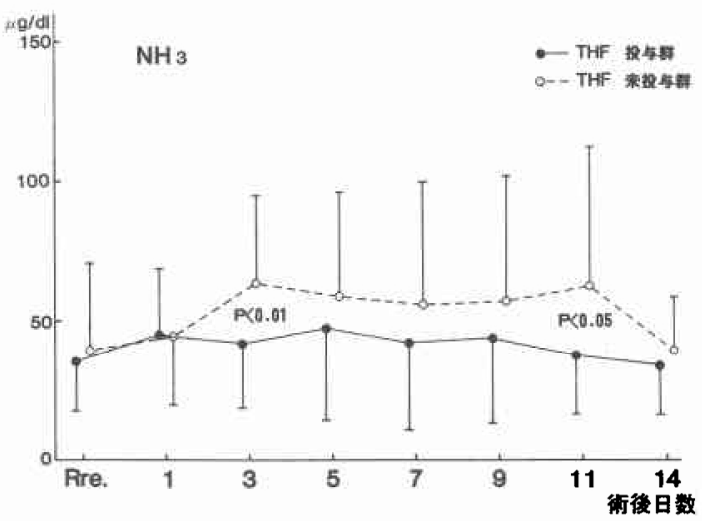


有意に低値を示した THF 投与群が 3 日目から11日目 までは術前とは逆に未投与群よりも高い值で推移し た. $\mathrm{NH}_{3}$ (図 6 ), T・B (図 7 ) は術後同様な動きをし ており, THF 投与群が 3 日目以降, 未投与群よりも低 く推移しており, 特に $\mathrm{NH}_{3}$ の術後 3 日目と11日目の THF 投与群は有意の低下を示した. GOT は（図 8) 術前 THF 投与群が有意隹高値を示して和り, 術後も ほ涪これと同様の差を保って推移し，未投与群との違 いは認めなかった。

4. 個々の血浆アミノ酸の推移（図 9 a〜f）

個々の血浆つミノ酸の推移をTHF 中に含有される 濃度別に検討した. Val, Leu, Ileu, Proline(以下 Pro), Alanine(以下 Ala) は THF に高濃度含まれているが, そのうち Val, Leu, Ileu は術後 1 日目に低下するすの の, THFにより高濃度輸液されるためか術後 3 日目 にはもら術前値近くか，それ以上に回復し，その後は 大きな変動は示さず推移した.これに対し Pro, Alaは 高濃度投与されているにもかかわらず術後 3 日目に最

図 7 THF 投与群と末投与群間の TB 値の比較

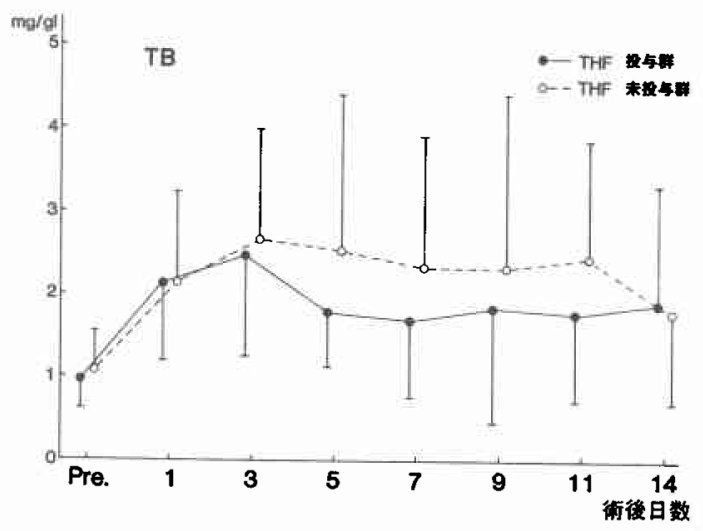

図 8 THF 投与群と末投与群間の GOT 値の比幹

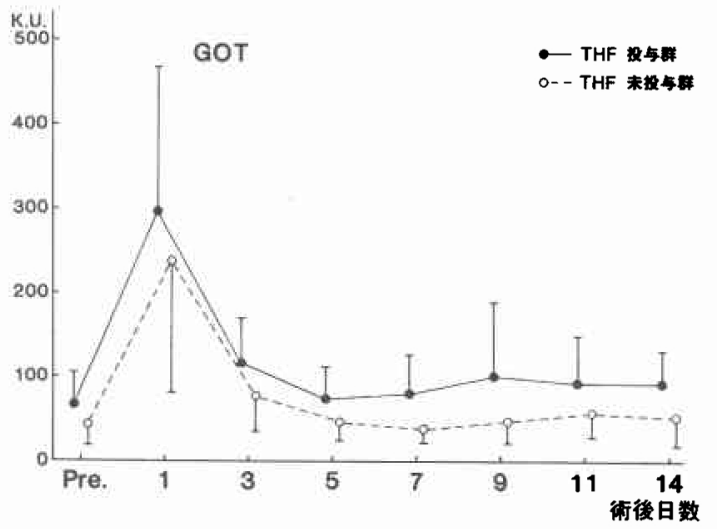

も低值を示した後, 術前値むでに回復するのに11日目 までを要した。次にTHFに中等度含まれる Threonine (以下 Thr), Serine (以下 Ser), Glycine (以下 Gly)，Histidine（以下 His）では His 以外は術 後11日目まで徐々に術前値に回復する推移を示した が, His は術前, 術後を通してほとんど同様の值で推移 しておりり，大きな変動は認めなかった，THFにごく少 量含まれているにすぎないPhe, Tyrは同じAAAで ありながら，その術後推移は大きく異っており，Tyr は術後 $1 ， 3 ， 5$ 日と低下し，7 日目で術前直以上に上 昇しているのに対し, Phe は術後 1,3 日之術前值より わずかに高く上昇した後は大きな変動は示さなかっ た. 最後にTHFに全く含まれていないGlutamic acid (以下 Glu) の術後推移をみると, 術後 1,3 日と 低下した後, 11日目に初めて術前值以上に上昇した。

5. 糖原性，ヶト原性了ミノ酸の術後推移(困 9 a

図 9 個々のアミノ酸の術後推移

的高濃度群 れ中濃度群

分低濃度群非含有群

糖 原 性...Pro. Ala. Gly. Thr. Ser. Glu. ヶト原性…Val. Leu. Ileu. His. Tyr. Phe. (図 9 a)
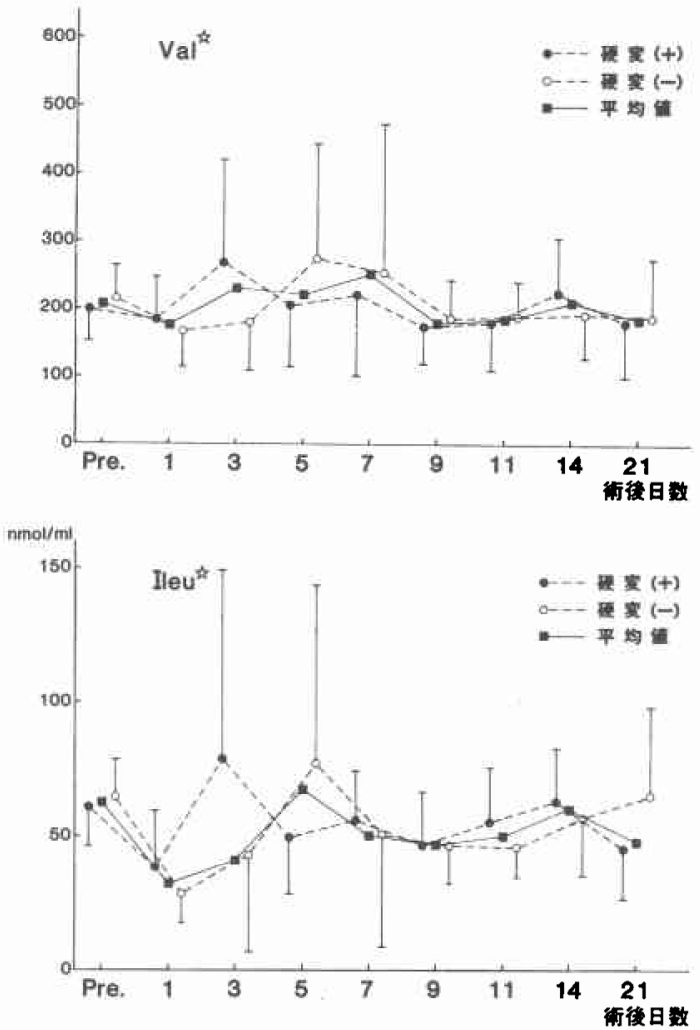
(図 9 b)
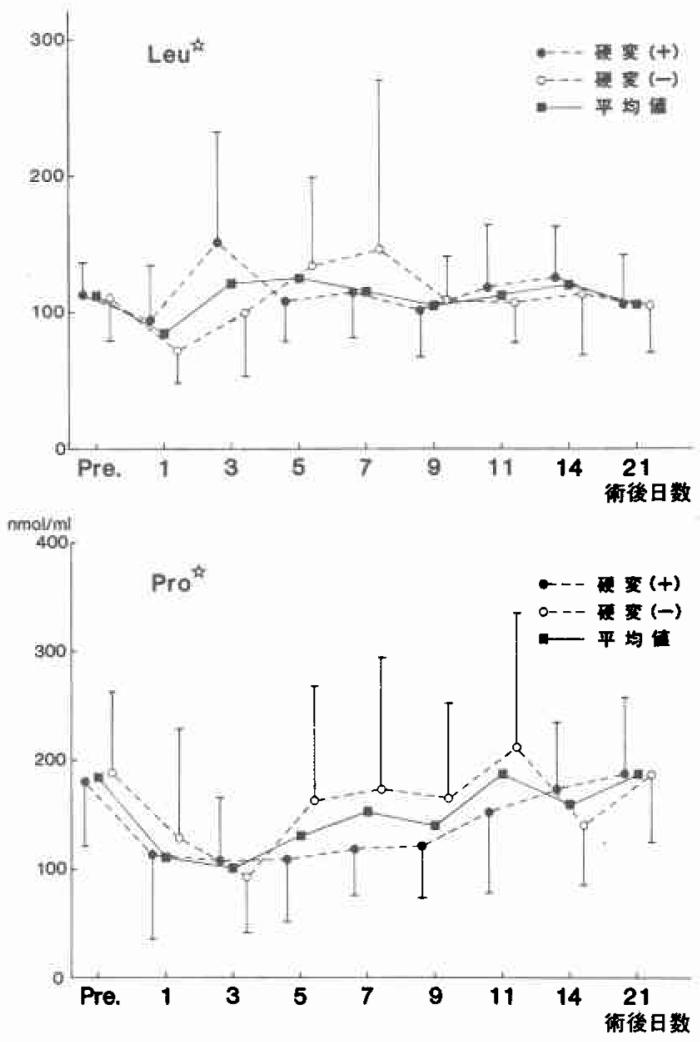

〜)

以上の12種のアミノ酸を別の観点から, 糖原性, ケ 卜原性の 2 つに分け，その術後推移を検討したが，ヶ ト原性のアミノ酸相互には大さな共通点は認められな いのに対し，糖原性の Pro, Ala, Ser, Gly, Thr, Gluの 6 種は, 術後早期に術前値よりる低下した後, 徐々に 上昇し，11日目でようやく術前值にまで回復するほ注 同様の推移を示す共通点が認められた。

\section{考察}

近年, 腹部超音波検查を中心とした画像診断の発達 は著しく, 肝切除の適応となるような微小な肝病変が 早期に発見されるようになった，そのら充肝臓外科の 分野では，この超音波装置を駆使した術式の確立など によって，肝切除が容易に行えるようになり，原発性 肝癌を中心とした多くの疾患に対して積極的に肝切除 が施行されている9．しかしながら，障害肝の切除や， 正常肝であっても大量肝切除を行うと, 術後に致命的 な肝不全に陥いる可能性があり, 術前の肝予備能の判 定, 術式の選択はもちろん, 術後の適切な栄養管理に より, 肝が元来もっている旺盛な再生能を活用し,す
(図 9 c)
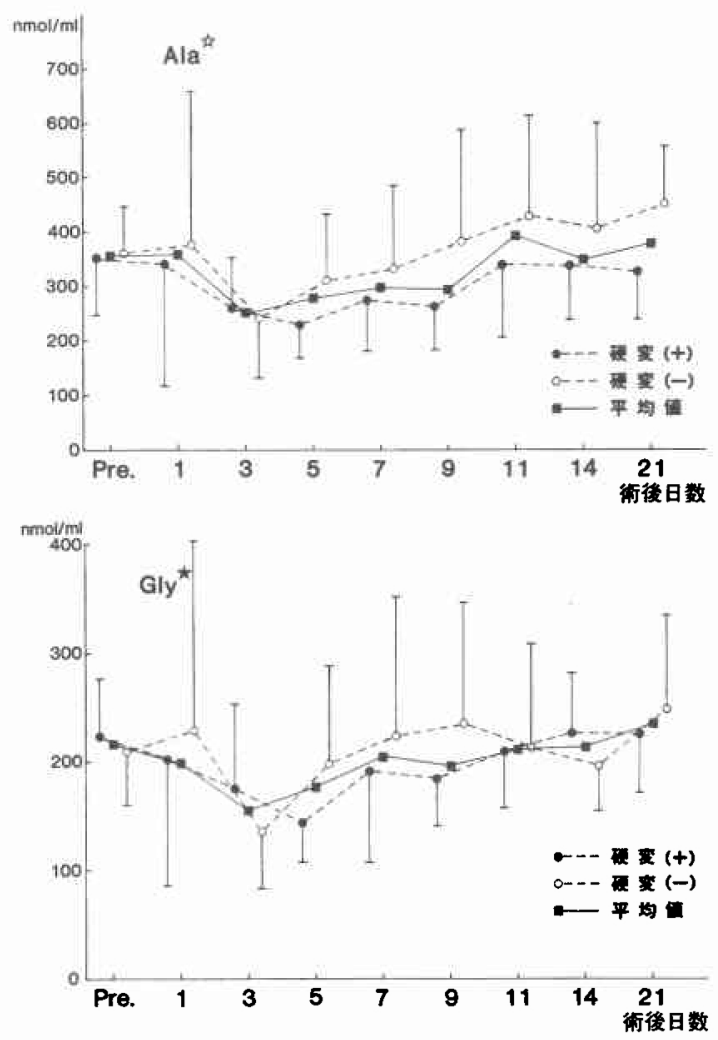

みやかに肝の量的, 機能的な回復をはかることにより， この肝不全を回避する努力が必要となる，肝切除の栄 養管理に関しては，古くはDavis ${ }^{10)}$ が Rat の肝切除後 に高蛋白, 高含水炭素食を与艺群とそうでない群と の比較をした報告など，かなり以前より研究がされて おり，最近では本邦に拈いても，多施設で，この栄養 管理に関しての多くの報告がみられる ${ }^{1112)}$. 肝切除後 の栄養, 代謝管理を行うに際して，いわゆる糖質，脂 質，蛋白質なと゚の栄養素の重要性について，それぞれ

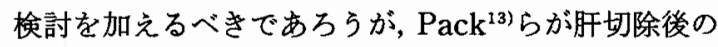
血清アルブミンの急速な低下を報じて以来, 肝切除後 においては，代謝の中心をなするのは蛋白代謝である とされている，乙かし，この蛋白代謝子独立したもの ではなく，糖，脂質代謝と相互に関連しあっており， 単一にとらえられるものではない，蛋白の元をなすア ミノ酸の代謝に関する報告は多いが，1974年以来, Fischer ${ }^{14)} ら は$ 肝硬変などの慢性肝疾患に拈いて, 血中 AAA，Metの上昇と BCAAの低下が認められ，この BCAA/AAA 比の低下が肝性脳症の発症進展に重要 な役割を果たしているとし，この状態にBCAAを投 
(図 9 d)
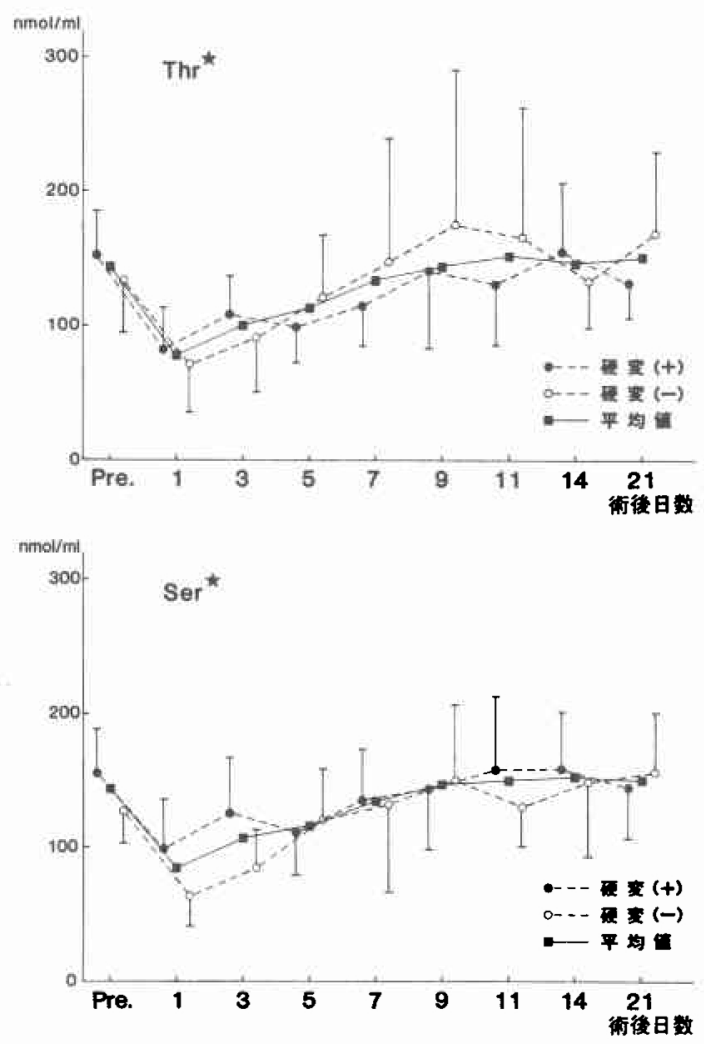

与することにより，血浆遊離アミノ酸のインパランス を正常化させ，肝性脳症を改善することができると報 告している，このインバランスの成因については，肝 硬変では門脈一大静脈短絡形成があり, インスリンの 不活化が行われず，高インスリン血症がみられる15) ともに, BCAA は骨格筋で代謝，その取り込みはイン スリン依存性であることが加わり, BCAAの取り込み が亢進し, 血中濃度の低下を招く ${ }^{16)}$ と考えられている. 末た Soeters ${ }^{17)}$ ら AAA の増加の原因はインスリ ン/グルカゴン比の低下による代謝の異化刺激と肝に 拈けるアミノ酸の処理能力の低下によるとしている. われわれの症例においても, 術前の血浆アミ，酸のイ ンバランスが認められ, AAA, Met が硬変例で有意に 上昇しており，BCAA，MR も硬変例で低值を示した。 この状態は肝切除によりさらに肝の代謝能力が低下 し， AAA が上昇することによって著しいものとなる ことが予想され, 肝性脳症の発生の危険性が増すこと になる. この血采フミノ酸のインバランスを改善する ことは, THF 投与の一つの目的であるが, 実際に, 術 後 $\mathrm{AAA}$ の著しい上昇は抑えられている. また BCAA
(図 $9 \mathrm{e}$ )
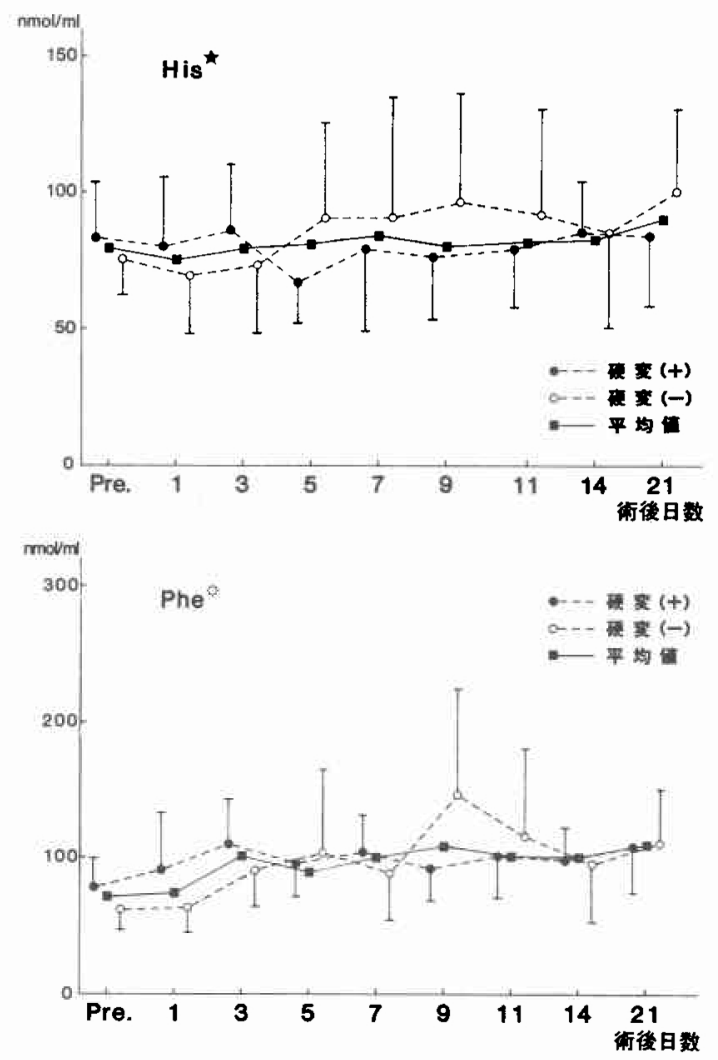

は骨格筋において代謝され，肝機能の良悪によって， その代謝はあまり影響を受けず，投与した BCAAを 反映してか，それだけ上昇しており，その結果として MRは高值で推移した，MRの低下により肝性脳症が 発生するとした Fischer ら5の理論から言党ぱ，その 予防の意味からも BCAA 輸液の投与は有用となる.

血清アルブミンの術後代謝に関しては，一般に手術 侵襲後において訮における蛋白合成機能の元進が認め

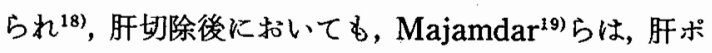
リゾームの蛋白合成能の増加によりアルブミンの合成 能が増加すると報告している。しかし，このように肝 切除後の肝における蛋白合成がさかんに行われている るのの, 肝容積が小さいため, その量が不十分であり, アルブミン合成が盛んになるのは 4 日以降であるとい 亏報告 ${ }^{18) 201211}$ 子みられる. 他方, 手術後は蛋白異化が元

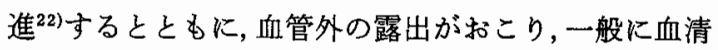
アルブミン濃度の低下が認められる。この結果, 䏛質 浸透压が低下し，アルブミン合成がふ活化されること になる ${ }^{18) 23\}}$.つまり,アルブミンの異化充進が著しい時 期においても，一方では肝に拈いてさかんにアルブミ 
(図 9 f)
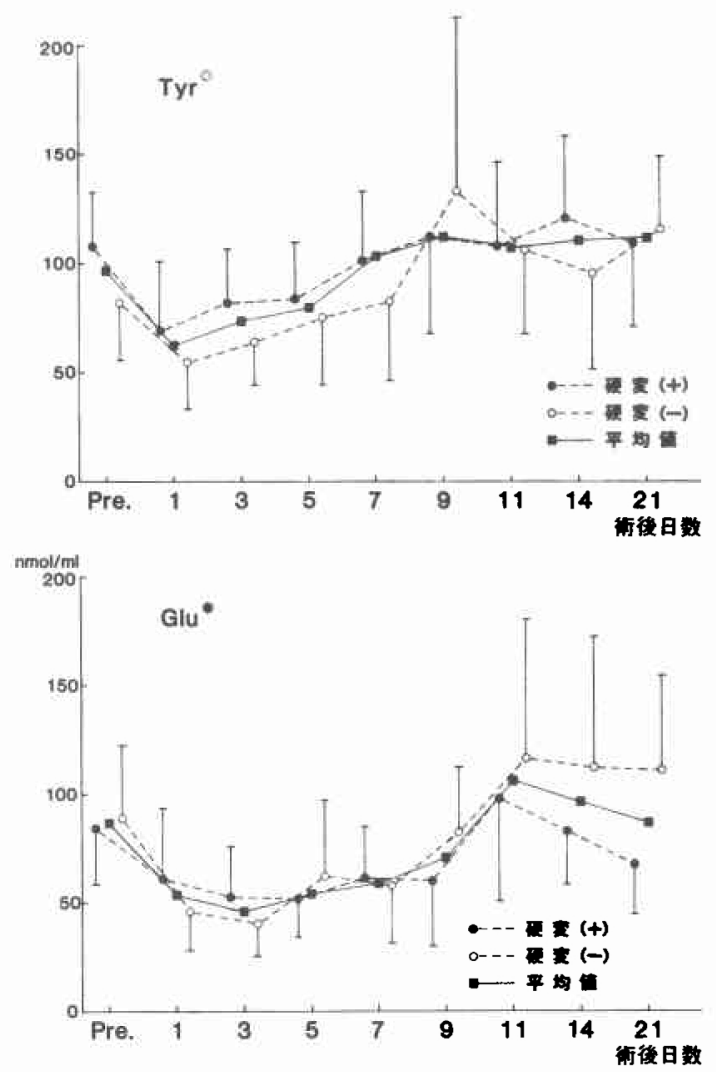

ン合成が行われ，血中に放出されているのである．今 回の症例の血清アルブミン值の推移をみると, THF 末投与群では, やはり術後低下するすのの, 投与群で はほとんど低下は認められず, 何らかの THFのアル ブミン合成への影響が示唆された。

肝切除後の肝機能を評価する検査の一つである HPT は, 血液凝固因子活性を測定したもので,これら の因子は肝で合成され，肝の蛋白合成能を正確に表現 するといわれている24225). 血清フルブミン值と同様に $\mathrm{HPT}$ 。術後早期の推移をみると THF 群に有効な差 が認められており，アルブミン合成に限らず，肝の蛋 白合成一般に THF の投与は良い条件を与えているの かもしれない.

肝性脳症に対して，大きな役割を果たしている高】 ンモニア血症に対して, 以前より, Arginine（以下 Arg), Glutamine や Ornithine, Asparagineなどのア ミノ酸製剂が，アンモニア濃度の低下剤として使われ てきた ${ }^{26)}$.しかし，これを肝切除後に使用するには 1 〜 2種のアミノ酸を大量に投与することがアミノ酸
プールの不均衡を助長させ，円滑な蛋白合成を障害す る点27)や，障害肝ではUrea生成酵素の Arg 活性が低 い点8)などについて疑問が残る。そこでフンモニア低 下作用があるといわれる ${ }^{29130)}$ THF を肝切除後に使用 したのだが，明らかに血清アンモニアの低下を認め， 高アンモニア血症の予防という点からは良好な結果を 得た。これは投与された大量のBCAAが骨格筋に よって代謝される際にアンモニアを積極的に摂取し， 解毒している機序によるものと思われる ${ }^{31) 321}$.

術後の BCAA 投与に関して,さらに大きな利点と なるものに, 術後の異化状態の改善ということがあげ られる. Cuthbertson ${ }^{33}$ が手術侵襲に伴ら代謝性変動 について, 酸素消費の増大と尿中窒素排泄の増加を報 告して以来, 外傷や手術侵襲により, 生体は体蛋白の 崩壊, すなわち異化に傾くことが知られている、これ に対し, 最近 sepsisや手術後の異化期において, $\mathrm{BCAA}$ の投与が蛋白代謝の改善,つまり Anticatabolic effectをむっていることが明らかとな $\eta^{34335)}$, 本邦に扔いても，薛ら ${ }^{36}$ は，14C-ロインンを用 いて tracer 実験により,フラニン合成を通じ14C-ロイ シンが糖新生に深く関与し, 術後のエネルギ一源とし て, 術後早期の BCAA の積極的投与を示唆している.

肝切除後の肝再生を迅速に進め, すみやかに術前の 大きさ，機能をるつ状態に回復したならば，それだけ 肝不全に宿いる可能性を少なくすることができると考 えられる。肝再生に対してアミ，酸がどのように関与 しているのかは，一つには肝再生の過程で蛋白合成， DNA 合成 ${ }^{37} に$ に括りる重要な素材としてアミ，酸が働 くことが考えられ, さらに質, 量の問題に対しては, 切除肝や培養肝細胞を使って，実験的に検討がなされ てきた ${ }^{38 / 39)}$. 15N-ロイシンを tracerとして硬変肝切除 後の残存肝に打ける蛋白合成能を測定し, 硬変肝切除 後に BCAA richなアミ，酸組成液の投与が有用であ

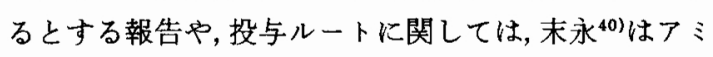
八酸を経門脈的に肝内投与すると DNA 標識率は末梢 静脈投与より有意に上昇して, 門脈血中のアミノ酸が 肝再生の促進に重要な役割を果すと報告している。本 研究では肝再生の直接的な指標となる血清学的, 形態 学的検査は行われておらず, 明確に結論づけることは できないが，既述の報告から，肝再生に対しても BCAA 輸液は促進的に働く可能性が示唆された。 また アミノ酸投与ルートは，われわれはすべて未梢静脈よ り投与したが, 経門脈的投与の方がより生理的であり, 肝再生に対してもより有効なルートである可能性が高 
いことなどを考光あわせると，容易には臨床的に沉用 し難いが, 経門脈投与の可能性について, 今後さらに 検討を加えたい。

肝切除後の血浆アミノ酸濃度の推移については, 圓 谷 ${ }^{41}$ は成犬の $70 \%$ 肝切除で認めた結果, 血清了ミノ酸 濃度は肝切除後に著しく増加した後 5 日目までに術前 值に戻り，特に phe，Tyr の增加が著しいことを報告 し，その原因としては，肝障害によるアミノ酸処理能 の低下, 組織蛋白の異化作用の亢進, アミノ酸プール からの逸脱が考えられると述べている。しかし，われ われの測定では, 術直後のPheの上昇は軽度であり, Tyr は逆に低下を認めた。さらに THFに多量に含ま れるにもかかわらず, Val, Leu, Ileu, Pro, Ala さえも 術直後の上昇は認められず, 術前值と同様か逆に减少 しており，THF投与が，血浆つミ八酸代謝の変化をる たらし，このような違いとなったものと思われる。つ まり, THFによる外来性のアミ，酸のみならず，これ らによる既存の血浆アミノ酸への影響により, アミノ 酸の直接的な酸化によるェネルギー源としての利用, 糖新生への利用, さらに蛋白合成への利用などがふ活 化され，血浆アミ/酸の低下をきたした可能性も考え られる.ことに glucogenic amino acidであるPro, Ala, Ser, Gly, Thr, Glu が術後に同じようなパターン で低下傾向を示した点を考虑すると，これらのアミ， 酸が糖新生へと利用されたことを強く示唆しているの かもしれない，しかし，アミノ酸の代謝は，一様に考 えられるすのではなく,たとえば, Ala ひとつについて る，手術侵襲後の肝に到達した Ala の主なる代謝経路 は糖新生への経路であり, 術後の高血糖の成因のひと つは肝における glucogenic amino acidからの糖新生 の克進であるとする報告42)や，逆にブドウ糖とAla を 同時に投与する場合，ブドゥ糖および Ala とも互い に，自身の酸化に対して相乗的な効果をむって抒り， Ala の直接的な酸化によるエネルギー源への利用を示 唆した報告 ${ }^{43)}$ などがあり,一つのアミ，酸についても， その状況の違いにより, 種々の代謝様式を示すことが 考えられる.

このように，BCAA 輸液投与は，有効之考学られた が，今回の43症例の予後をみると， 3 症例が肝不全に 陥り死亡した。術前の肝予備力は, この 3 症例を含め, 十分にそれぞれの術式に耐兄らるすのであり44)，その ら充, 肝不全の原因として,それぞれ術後の断端部大 量出血, 閉塞性黄㾝, 急性荤炎といらアクシデントか゚ 大きく関与していたことを考完あわせると，この肝不
全は，BCAA を中心とする栄養輸液だけでは，防ぎえ るものではなかったものと考兄られ，栄着管理といら 一つの方面だけではなく，総合的な術後管理の努力の 必要性が痛感させられた。

\section{結 論}

肝切除患者 43 症例飞対して, 術後 BCAA 輸液 （THF）を投与し，血浆 $ミ$ 〉酸， HPT, $\mathrm{NH}_{3}, \mathrm{GOT}$, $\mathrm{Alb}, \mathrm{T} ・ \mathrm{~B}$ を測定することにより，その有効性について 検討した結果，次のような結論を得た。

1. 肝硬変症例の術前に括いて, AAA, BCAA, Methionine のインバランスが認められた。

2. 肝切除後の AAA, BCAAのインバランスが BCAA 輸液により補正された。

3. Alb 合成を初めとして，HPTよりみて，肝の蛋 白合成に BCAA 輸夜は促進的に働いた。

4. BCAA 輸液は, 明らかな $\mathrm{NH}_{3}$ 低下作用を示し, 術後の $\mathrm{NH}_{3}$ 上昇防止に有効であった。術後早期のエネ ルギー源としての BCAA 輸液の有用性が示唆され た.

稿を釉わるにあたり御指導，御校閲を賜わりました古賀 道弘教授に深甚なる感謝の意を表わすととるに，直接御指 導を頂きました中山和道助教授，才津秀樹先生をはじめ，本 研究に御男力を頂いた研究室員一同に心よりの謝意を捧げ ます。な拈, 本論文の要旨は第69回日本消化器病学会総会抒 よび第21回日本消化器外科学会総会に括いて発表した。

\section{文献}

1）服部 信, 野田八嗣, 田中延善ほか：インスリン・ グルカゴン療法の理論的背景. 日臨 $40: 831$ $-836,1982$

2）葛西洋一, 圓谷敏彦：肝切除と術前後の栄盖管理。 手術 35:1363-1371，1982

3）佐藤 博, 碓井貞保: 訮荿手術. 消外 $6: 425$ $-431,1983$

4) Walshe JM: Disturbances of amino acid metabolism following liver injury: Study by means of paper chromatography. Q J Med 22 : $483-505,1953$

5) Fischer JE, Rosen HM, Ebeid AM et al: The effect of normalization of plasma amino acids on hepatic encephalopathy in man. Surgery $80: 77-91,1976$

6）武藤泰敏：肝不全用特殊組成 種類・成分比. 投与法. 日臨 $40: 817-823,1982$

7) 三條健昌, 比田井耕, 和田達雄注か：肝不全用了ミ 〉酸輸液 THF 执よび顆粒 THF-GKついて。 THF 研究会会報 $1: 1-9,1980$

8）海藤 勇, 鈴木一幸, 加藤章信浪か：分枝鎖了ミ， 酸輸液の肝性昏睡覚醒効果. 日臨 $40: 811-816$, 1982

9）日本肝癌研究会：原発性肝癌に関する追跡調查. 
肝臓 $23: 675-681,1982$

10) Davis NC, Whipple GH: Liver regeneration following chloroform injury as influenced by various diet. Arch Int Med 23:711-722, 1921

11）葛西洋一, 圓谷敏彦: 肝切除後の栄養管理. 手術 $35: 1363-1371,1981$

12）岡本英三, 山中若樹 : 肝切除後の管理. 消外 2 : 1207-1212, 1979

13) Pack GT, Baker HW: Total right hepatic lobectomy. Ann Surg 138:253-258, 1953

14) Fischer JE, Yoshimura N, Aguirre A et al: Plasma amino acid in patients with hepatic encephalopathy. Am J Surg 127: 40-47, 1974

15) Greco AV, Crucitti F, Ghirlanda G: Insulin and glucagon concentrations in portal and peripheral veins in patients with hepatic cirr. hosis. Diabetologia $17: 23-28,1979$

16) Muro HN, Fernstrom JD, Wurtman RJ: Insulin, plasma amino acid imbalance and hepatic coma. Lancet $1: 722-724,1975$

17) Soeters PB, Fischer JE: Insulin, glucagon, amino acid imbalance, and hepatic encephalopathy. Lancet $2: 880-882,1976$

18）薛 光明：手術侵襲後のエネルギー。蛋白代謝に 関する実験的研究. 日外会誌 $83: 1177-1189$, 1982

19) Majamdar C, Tsukada K, Lierman L: Liver protein synthesis after partial hepatectomy and acute stress. J Biol Chem 242: 700-704, 1967

20) Braun GA, Marsh JB, Drabkin DC: Synthesis of plasma albumin and tissue proteins in $r$ egenerating liver. Metabolism 11: 957-966, 1962

21）圓谷敏彦：肝再生とアミノ酸代謝に関する研究。 日外会誌 $82: 748-758,1981$

22）武藤輝一，小山 真, 岩㴊 真ほか：蛋白代謝. 手 術 25:977-984，1971

23) Rothschild MA, Oratz M, Evans $C D$ et al : Role of hepatic interstitial albuminin regulating albumin synthesis. Am J Physiol 210 : $57-62, \quad 1966$

24）竹谷 弘：肝切除術とへパプラスチンテスト。外 科治療 $12: 1715-1718,1979$

25）大塚雅昭：肝切除後の rapid turn over serum proteinの変動。日消外会誌 $16: 1678-1683$, 1983

26) Najarian JS, Happer HA : Comparative effect of arginine and mono sodium glutamate on blood ammonia. Proc Soc Expt Biol Med 92 : $560-563,1956$

27）渡辺明治, 東 浚宏, 小畑尚宏ほか：劇症肝资の治 療に打壮る分枝鎖了ミノ酸輸液の臨床的意義。肝 臓 $20: 702-713,1979$

28) Wolfe SJ, Fast BB, Stormont JM et al : Treatment of hepatic coma: Use of krebs urea cycle intermediation (1-arginine, dl-ornithine). J Lab Clin Med $51: 672-689,1958$

29）三條健昌, 北田井耕, 川崎誠治ほか：THF に関す 万基礎的研究. THF 研究会会報, 第 4 巻, 近代企 画, 1981, p174-187

30）神代龍吉, 前山豊明, 丸山 泉ほか：特殊組成つミ 八酸輸液 THF の使用経験. 肝性脳症 30 例での臨 床効果. 薬理と治療 $10: 755-783 ， 1982$

31) Lockwood AH, Mcdonald JM, Reiman RE: The dynamics of ammonia metabolism in man. Effects of liver diseace and hyperammonemia. J Clin I Invest $63: 449-460,1979$

32）橋本 修, 林 真功, 盲藤公志郎注か：肝性脳症に おけるアミノ酸代謝とその治療. 臨科 $17: 1290$ $-1300,1981$

33) Cuthbertson DP: The disturbance of metabolism produced by bony and non-bony injury. with notes on certain abnormal conditions of bone. Biochem J 24:1244-1263, 1930

34) Freud H, Hoover HC, Atamian $\mathrm{S}$ et al: Infusion of th branched chain amino acids in postoperative patients. Ann Surg $190: 18-23,1979$

35) Blackburn GL, Moldawer LL, Usui $S$ et al : Branched chain amino acid administration and metabolism during starvation, injury and infection. Surg $86: 307-315,1979$

36) 薛 光明, 吉川恵次, 勝井 豊ほか：術後早期のア ミ，酸代謝の研究一筋組織を中心として一. 外科 と代謝・栄養 $15 ： 57-64,1981$

37) Cater DB, Holmes BE, Mee LK : Cell division and nucleic acid synthesis in the regenerating liver of the rat. Acta Radiol 46:655-667, 1956

38) Mondon GE, Mortimore GE : Effects of insulin on amino acid release and urea formation in perfused rat liver. Am J Physiol $212: 173-178$, 1967

39) Fischer MM, Kerly M: Amino acid metabolism in the perfused rat liver. J physiol $174: 273-294,1964$

40）末永昌宏：肝切除後の再生に関わる門脈性因子に ついての実験的研究一特にアミノ酸の果す役割り について一。目外会誌 $84: 424-436,1983$

41) 圓谷敏彦: 訮再生とアミノ酸代謝に関する研究. 日外会誌 $82: 748-758,1981$

42）吉川恵次, 薛 光明, 三科 武は加：手術侵㜔に伴 5肝でのアラニンからの糖新生. 外科と代謝・栄養 $16: 55-64,1982$

43）百瀬健彦, 芳田一宏, 前田正之ほか：手術侵襲之脂 肪乳剂, ブドウ糖およびアラニンのエネルギー代 謝に拈ける相互関係. 外科と代謝・栄羡 $15: 97$ $-102,1981$

44）野口孝, 水本龍二：肝癌の切除療法一肝の予備 力を中心とした手術適応規準一. 肝・胆・膵 5 : $1089-1095,1982$ 